\title{
Study on Food Import in D. R. Congo
}

\author{
Mukeba Mbala Eric ${ }^{1,2}$, Shiwei Xu1,2*, Wen Yu1,2, Shengwei Wang1,2, Abdul-Gafar Ahmed1,2, \\ Siek Darith ${ }^{1,2}$, Mujinga Bukasa Eliane ${ }^{1,2}$ \\ ${ }^{1}$ Agricultural Information Institute, Chinese Academy of Agricultural Sciences, Beijing, China \\ ${ }^{2}$ Key Laboratory of Digital Agricultural Early-Warning Technology, Ministry of Agriculture, Beijing, China \\ Email:machaoeric741@gmail.com,xushiwei@caas.cn,yuwen@caas.cn,wangshengwei@caas.cn
}

How to cite this paper: Eric, M.M., Xu, S.W., Yu, W., Wang, S.W., Ahmed, A.-G., Darith, S. and Eliane, M.B. (2017) Study on Food Import in D. R. Congo. World Journal of Engineering and Technology, 5, 2330 .

https://doi.org/10.4236/wjet.2017.52B003

Received: April 11, 2017

Accepted: June 26, 2017

Published: June 29, 2017

\begin{abstract}
Democratic Republic of Congo is a developing country located in Central Africa with a population of over 75 million. Generally, it relies on import in international market for food as it has constantly been experiencing domestic crisis which hinders production. Given the importance of shores price policy and income policy, the government pays meticulous attention to these factors to meet the present and future food security. In order to understand the import behavior related to GDP and international trade prices, the study employs Almost Idea Demand System (AIDS) model using FAO data. The result explains that price effect is more useful to the food security of the country than the income effect, thus this study suggest the government should give priority to policy on price.
\end{abstract}

\section{Keywords}

Agricultural Import, Almost Ideal Demand System (AIDS), D. R. Congo, Policy

\section{Introduction}

More of the poor population lives in the rural regions and are highly dependent on agriculture for their livelihood in D. R. Congo and in other developing country in the world [1]. The Agriculture in the world is the principal of economic development these nations [2]. In Africa, the major agricultural growth opportunities will be in regional and domestic markets for food staples. To seize these opportunities, there should be continued and sound macroeconomic policies to further improvements in the investment in infrastructure and institutions [3] [4]. At least four out of every ten children suffer from stunted growth due to poor nutrition. Since no enough is grown locally to meet demand, supplies have to be brought in from outside. With rising global prices, it is hard for families to afford imported food. 
In this study, we focus on the food issue in The Democratic Republic of Congo, including agricultural production, trade and the relation to its prices. Using the Almost Ideal Demand Model (AIDS), the study analyzes how the price and GDP influence the food import in D. R. Congo. The study provides and updates food security situation of D. R. Congo relative to its importation prices.

\section{Data and Its Description}

\subsection{Data Area}

The Democratic Republic of Congo is very rich country with natural resources; the political instability makes the country experience slow development and the difficult infrastructure, the world of commercial product exploitation is from colonial extraction with a little development. Prior to 1997, D.R. Congo was called Zaire (see Figure 1). It is located in Central Africa. It borders with the Republic of the Congo, the Central African Republic, and to the north, South Sudan, to the east- Uganda, Rwanda, Burundi and Tanzania; to the south-Zambia and Angola; and to the west-the Atlantic Ocean. D.R. Congo is the second largest country in Africa by area, the largest in Sub-Saharan Africa, and the eleventh largest in the world with a population of over 75 million. It location is in the equatorial and humid tropics experiencing an average temperature of $25^{\circ} \mathrm{C}$ around the bowl, from $26^{\circ} \mathrm{C}$ on the coast $18^{\circ} \mathrm{C}$ to $20^{\circ} \mathrm{C}$ at the altitude of 1500 meters, $16^{\circ} \mathrm{C}$ to $17^{\circ} \mathrm{C}$ in $2000,11^{\circ} \mathrm{C}$ to 3000 meters and $6^{\circ} \mathrm{C}$ to 4000 meters. The Democratic Republic of Congo has generally two seasons, that is to say, dry and rain.

\subsection{Data Source}

All data in this study originates from United Nation Food and Agricultural Organization (FAO). Categorically the data concentrates on 5 groups of common food in the country including staple food (cassava, maize, rice, millet, beans), livestock, oil-fat, milk and sugar. Their cultivated area, the total output and yield were also collected.

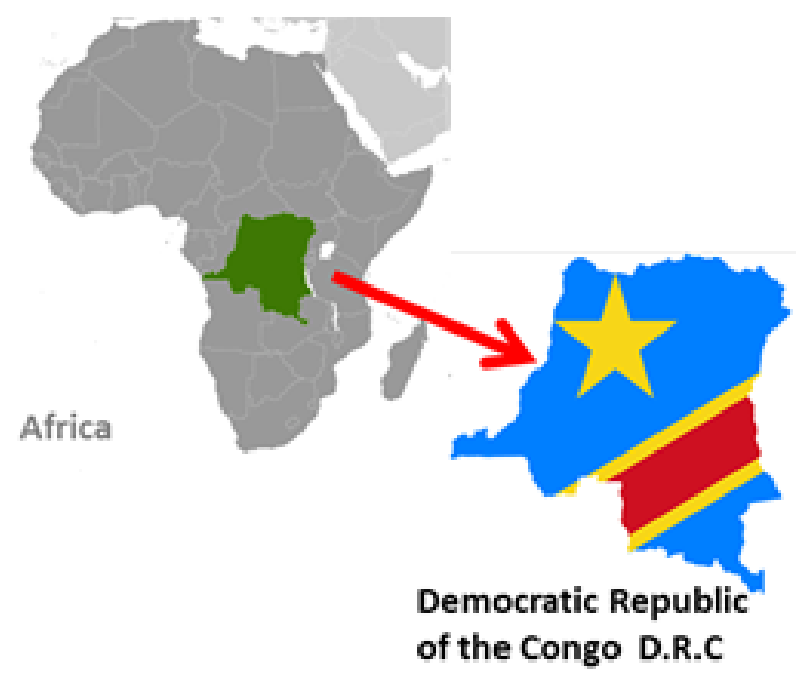

Figure 1. Map of democratic republic of Congo in Africa. 
At first, the crop structure and their production are introduced beginning with cassava, maize, rice, millet, beans, cowpeas, pulsesnes, banana, peanut, oil palm, sesame, soybeans, bananas, root tuber, vegetable, sweet potatoes, coffee, tea, cotton, sugarcane. Secondly, the trade of the above mentioned is presented.

\subsection{Crop Structure Changing}

Figure 2 shows the crop structure of a 54 year data from 1969 to 2014. It lists 20 kinds of staple crops by five groups according to row listing, which includes staple foods, beans, oil materials, vegetable and fruits, and economic crops. These are described in detail in the following.

1) Staple food (first row in Figure 2), including tuber-cassava, and staple grains-maize, rice, millet. From1994-1999, cassava had an increased in yield then starts declining after 2000. The reason for this sharp decline was as a result of the crisis during that period. Ever since, the yield has been declining. Maize on the other hand was experiencing increase until 1995 where yield remains relatively stagnant. Millet yield experiences a spike in 1997 and then dropped back to its normal trend in the following year.

2) Beans (second row of Figure 2), area bean-like crops, including cowpeas, pulses, Bambara beans. From 1995-1997, beans yield increased to $25.5 \mathrm{~kg} / \mathrm{ha}$ and
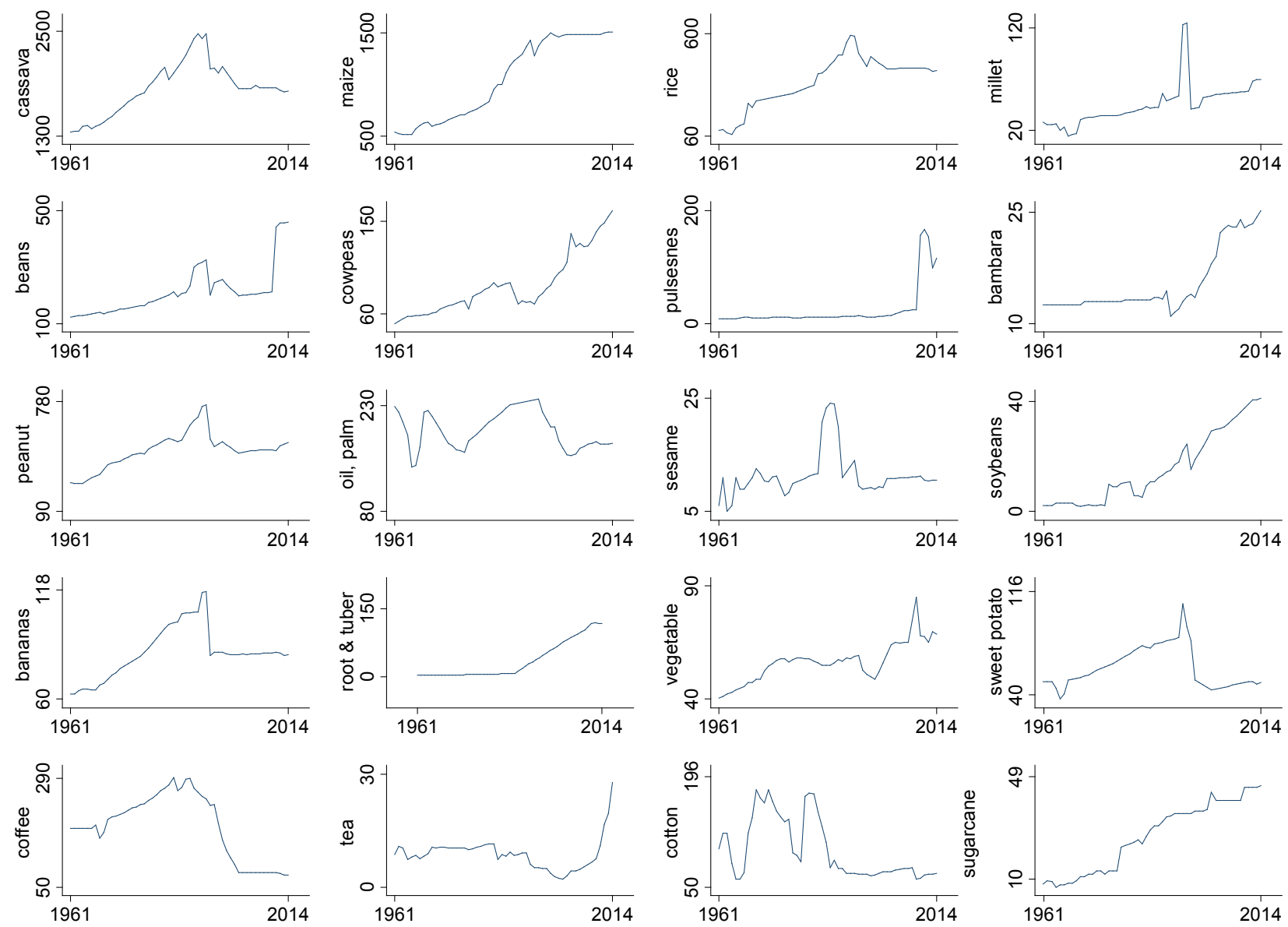

Figure 2. Crop structure area of D.R. Congo from 1961-2014 (Source: FAO, 2014). 
from 2002-2014 increased further to $45.7 \mathrm{~kg} / \mathrm{ha}$. Cowpeas, from 1985-2000 had an increase of about $95 \mathrm{~kg} / \mathrm{ha}$ and from 2010-2014 further increased with about $15.5 \mathrm{~kg} / \mathrm{ha}$. Pulses, from 1980-2005, yield was stable and then experienced an sharp increase in 2010 and then dropped with about $20 \mathrm{~kg} / \mathrm{ha}$ and from 2010-2012. Bambara from 1996-1997 decrease with about $13.9 \mathrm{~kg} / \mathrm{ha}$ and then from $2010-2014$ sky-rocketed to about $25.2 \mathrm{~kg} / \mathrm{ha}$.

3) Oil crops (third row of Figure 2), including-peanut, oil palm, sesame and soybeans. From 1990-1994, peanut yield increased to $75.8 \mathrm{~kg} / \mathrm{ha}$ and from 1999-2014 decreased to $50.1 \mathrm{~kg} / \mathrm{ha}$. Oil palm, from 1994-2003 decrease to 160 $\mathrm{kg} / \mathrm{ha}$ and them from 2010-2014 increase $175 \mathrm{~kg} / \mathrm{ha}$. Sesame, from 1961-1994, it yield has been fluctuating but sky-rocketed in 1995-1997 after which it dropped back to it normal trend prior to 1995 .

4) Roots \& tubers, vegetables and fruits (forth row of Figure 2), including bananas, sweet root \& tubers-potato, vegetable. Bananas, from 1961-1998 has been experiencing increasing yield until 2002 when the yield dropped sharply then maintained the low yield to 2014. Vegetables yield has been increasing since 1961 but highly fluctuating. On the other hand, the yield of sweet potato continued to increase from 1961-1999 after which it dropped as low as that of 1960s then continued to maintain same low yield till ever since.

5) Economics crops (fifth row of Figure 2), including coffee, tea, cotton, and sugarcane. The coffee, from 1988-1990, D.R Congo experienced the highest yield but after this period, yield began to decline even lower than that of the 1960s. Cotton, from 1961-1988, cotton production has been highly fluctuating. After 1988 it production became relatively stable but lower than the peak production experienced in 1983. Sugar is the only cash crop that maintained constant increase since 1961. As at 2012, about 45.5 thousand tons was produced (see Figure 3).

\subsection{Agricultural Production}

Cassava (Figure 3) during 1961-1994, the cassava production increase but continued to decline afterwards. Congo experienced the highest cassava production in 1992 which see a production of about 19.8 million tons. Maize production, during the period 1961-1994, the maize production was increasing and then declined for a short period (in 1995) and then rose back 1998. After this period, it production has been relatively stable. Groundnut production, just as maize production, it was increasing from 1961-1994 and then dropped from 0.6 million ton to 0.4 million tons in 1995. Afterwards it production maintained the same low level. Sesame production kept fluctuating from 1961-1982. In 1985, production spikes up from 5.3 thousand tons to 13.2 thousand tons in 1988 and 1989. Afterwards, it production dropped as low as 5.5 thousand tons in 1991 then remained stable at that level. Animal protein food, including meat, egg, and milk production; these foods have been relatively increasing with little fluctuations except in milk production. During the 1990s, milk production dropped drastically as a result of the crisis thus forcing the nation to import from other 

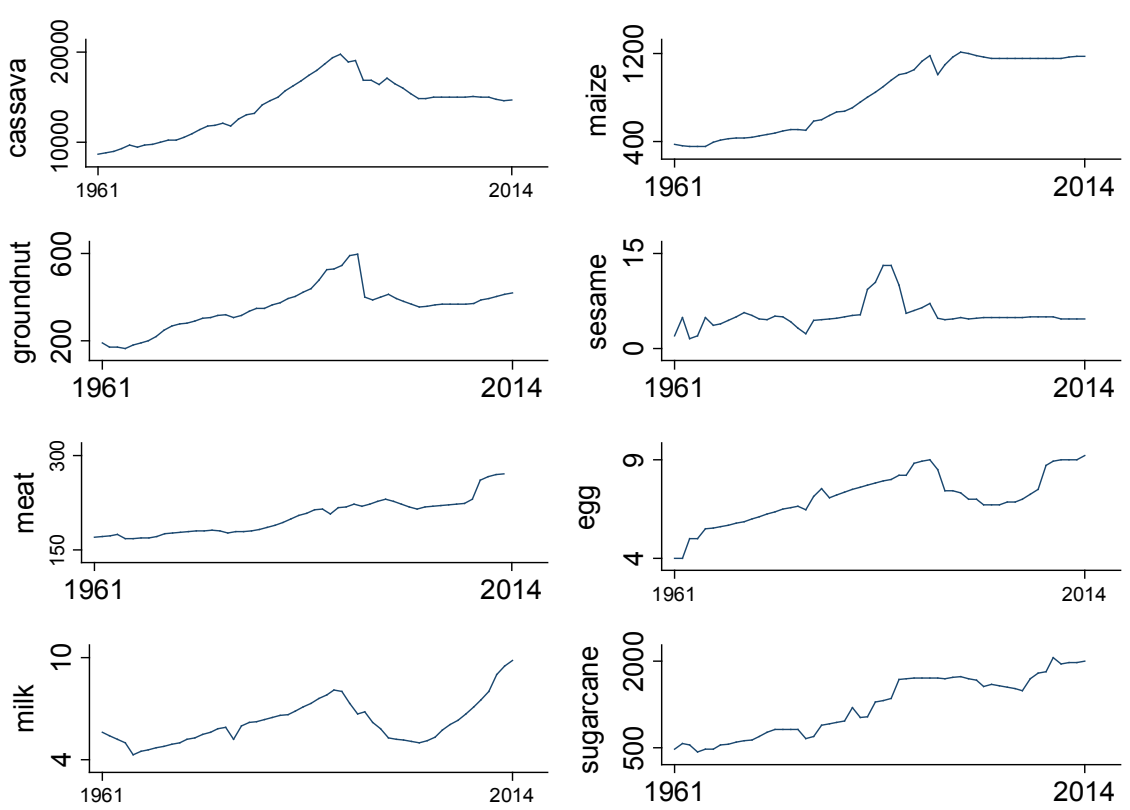

Figure 3. Agricultural production of D.R. Congo from 1961-2014 (Source: FAO, 2014).

countries.

\subsection{Trade}

Figure 4 shows the import quantities and values for grain, meat, oil fat, milk, and sugar from 1961 to 2013. The figure shows that in most of the agricultural trade, D.R. Congo experiences trade export deficit..That is to say, import has been greater than export throughout the year 1961 to 2013. Although the country exports more oil-fat prior to 1989 but afterwards import exceeds export followed by zero export.

\section{AIDS Model}

This section showed how to fit a quadratic almost ideal demand system (AIDS). Here we show how to fit the basic AIDS model by using nlsur. shows how to fit the quadratic AIDS model usingnlsur. the dataset food. dta contains import expenditures, expenditure share, and log prices for four broad food groups. For a four-good demand system, we need to fit the following system of five equations:

$$
\mathcal{W}_{1}=a_{i}+\sum_{i=1}^{5} g_{i j} * \ln p_{i}+b_{i} \ln \left\{\frac{m}{p(p)}\right\}+u_{1}
$$

where $w_{k}$ denotes a fraction of expenditures share on good $\mathcal{K}, \ln p_{\mathcal{K}}$ denotes the logarithm of the price paid for good_k, mdenotes a import total expenditure on all four goods, the $\mathcal{U}$ 'S are regression error terms, and

$$
\ln P\{p\}=\alpha_{0}+\sum_{i=1}^{5} \alpha_{i} \ln p_{i}+\frac{1}{2} \sum_{i=1}^{5} \gamma \ln p_{i} \ln p_{j}
$$

The parameters for the fourth good's share equation can be recovered from the following constraints that are imposed by economic theory: 
Quantity
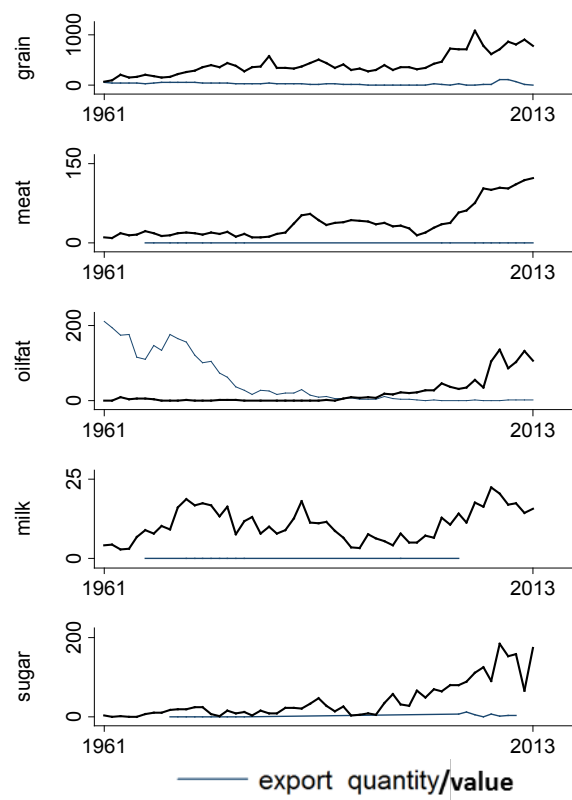

Value
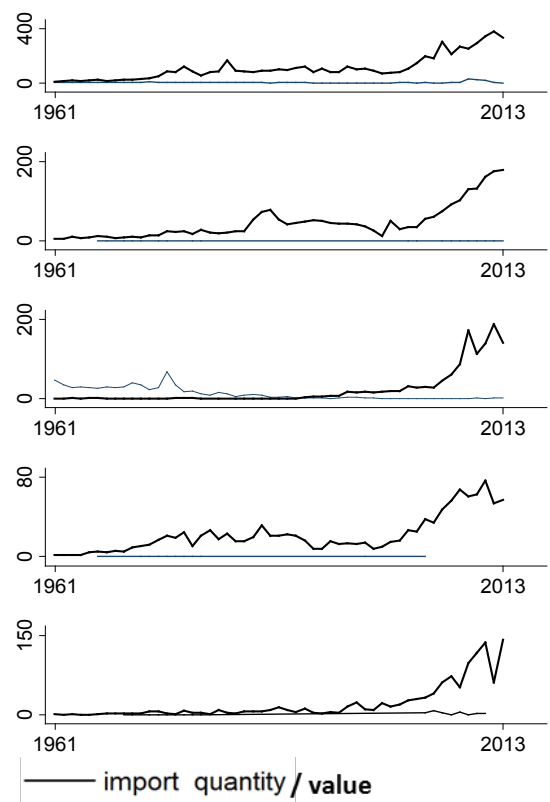

Figure 4. Agricultural trade of D.R. Congo from 1961 to 2013.

$$
\sum_{i=1}^{5} \alpha_{i}=1 \sum_{i=1}^{5} \beta_{i}=0 \quad \gamma_{i j}=\gamma_{j i} \text { and } \sum_{i=1}^{5} y_{i j}=0 \text { for all } j
$$

Our model has a total of 12 unrestricted parameters. We will not estimate directly. Instead, we will set it equal to 5 as was done in Poi (2002); see Deaton and Muellbauer (1980) for a discussion of why treating as fixed is acceptable.

\section{Price Elasticity and Import Expenditure Elasticity}

Import expenditure elasticity: The expenditure elasticity of demand in certain period, The expenditure elasticity of demand in consumption expenditure changes in demand for certain degree of change caused by the extent of the value if positive, that consumption and consumption expenditure changes in the same direction, number represents the degree of influence on it, the larger the value, when the total expenditure of living consumption after the increase, the consumption of good larger. The expenditure elasticity is in the following:

$$
\varepsilon_{i}=1+\frac{b_{i}}{w_{i}}
$$

The price elasticity of demand can be calculated by using the AIDS model, which can be used to calculate this self-price elasticity and cross price elasticity of production. Own-price and cross-price elasticity: when $i=j$, since the price elasticity, this time $\delta_{i j}=1$. Since the price elasticity is negative, that consumption and prices reverse, with rising commodity prices, the number of rural resident consumption of the goods decreased value represents the size of the impact of price change son consumption. When $i \neq j, \delta_{i j}=0$. The price elasticity is in the following: 


$$
\eta_{i j}=-\delta_{i j}+\frac{g_{i j} * b_{i} * w_{j}}{w_{i}}
$$

\section{Result and Discussion}

The R square $\left(\mathrm{R}^{2}\right)$ explains how well the function (W) supports the coefficients of the variables. All the functions had more than $90 \%$ acceptance. The import share is decided mainly by the logarithm of Own price excluding milks and sugar. The price and expenditure elasticity of staple food is presented in Table 1.

From Table, according to the function of expenditure elasticity and price elasticity, the needed elasticities are listed in Table 2. The oil fat own-price elasticity was slightly lower them other food. As shown the import expenditure is relatively similar to the ratio of the own price change. Most of the cross-price elasticity within the staple food was positive, implying that the major food items can be substituted. The oil fat was complementary to the grains and sugar, while the milk is a complement food to the meat, as shown by the negative cross-price elasticity.

\section{Conclusion}

Import expenditure elasticity is less than price elasticity for two of staple food

Table 1. AIDS model coefficient.

\begin{tabular}{cccccccccc}
\hline & & \multicolumn{2}{c}{$\begin{array}{c}\text { Coef. Of } \\
\text { determ. }\end{array}$} & & \multicolumn{2}{c}{ Price elasticity Coef. $\left(\mathrm{g}_{\mathrm{ij}}\right)$} & & $\begin{array}{c}\text { Expenditure } \\
\text { elasticity. }\end{array}$ \\
\hline function & denotion & $\left(\mathrm{R}^{2}\right)$ & $\begin{array}{c}\text { Staple } \\
\text { food }\end{array}$ & Livestock & Oil-fat & milks & sugar & $\mathrm{b}_{\mathrm{i}}$ \\
\hline $\mathrm{W}_{1}$ & Staplefood & 0.9932 & -0.1130 & -0.0044 & 0.0451 & -0.0054 & -0.0101 & -0.0383 \\
& & & $(-1.41)$ & $(-0.12)$ & $(1.29)$ & $(-0.17)$ & $(-0.57)$ & $(-3.22)$ \\
$\mathrm{W}_{2}$ & Livestock & 0.9793 & & -0.1782 & 0.0504 & 0.0572 & 0.0138 & -0.0162 \\
& & & & $(-4.45)$ & $(1.81)$ & $(2.35)$ & $(1.05)$ & $(-1.82)$ \\
$\mathrm{W}_{3}$ & Oil-fat & 0.9293 & & & -0.0531 & -0.0033 & 0.0109 & 0.0148 \\
& & & & & $(-1.93)$ & $(-0.19)$ & $(1.12)$ & $(2.01)$ \\
$\mathrm{W}_{4}$ & Milks & 0.9493 & & & & 0.0206 & 0.0012 & 0.0179 \\
& & & & & & $(0.89)$ & $(0.11)$ & $(2.58)$ \\
$\mathrm{W}_{5}$ & \multirow{2}{*}{ Sugar } & 0.9101 & & & & & -0.0108 & 0.0021 \\
& & & & & & & $(-1.41)$ & $(0.53)$ \\
\hline
\end{tabular}

Table 2. Import of price elasticity and expenditure elasticity.

\begin{tabular}{ccccccc}
\hline \multirow{2}{*}{ n_ij } & \multicolumn{5}{c}{ Price elasticity } & Import Expenditure \\
\cline { 2 - 6 } & grains & meat & oil fat & milk & sugar & Elasticity \\
\hline grains & -0.9957 & 0.0001 & -0.0002 & 0.0000 & 0.0000 & 0.9202 \\
meat & 0.0002 & -0.9971 & -0.0002 & -0.0005 & -0.0001 & 0.9165 \\
oilfat & 0.0067 & 0.0030 & -1.0008 & -0.0001 & 0.0002 & 1.3083 \\
milk & -0.0005 & 0.0020 & 0.0000 & -0.9996 & 0.0000 & 1.1808 \\
sugar & -0.0002 & 0.0001 & 0.0000 & 0.0000 & -1.0000 & 1.0382 \\
\hline
\end{tabular}


groups including grains and meat, which means that price effect is much more useful than income effect for important staple food. So the government should give priority to price policy. For oil fat, milk, and sugar, expenditure elasticity is greater than price elasticity, which means income policy has more affect their price policies (see Table 2); according to the expenditure elasticity and price elasticity, the country should have priority to encourage developing oil fat industry.

\section{Acknowledgements}

This paper was supported by the CAAS Science and Technology Innovation Project (number: CAAS-ASTIP-2017-AII), founded by Chinese Academy of Agricultural Sciences.

\section{References}

[1] Gollin, D. (2010) Agricultural Productivity and Economic Growth. Handbook of Agricultural Economics, 4, 3825-3866. https://doi.org/10.1016/S1574-0072(09)04073-0

[2] Norton, R.D. (2014) Policy Frameworks for International Agricultural and Rural Development. Encyclopedia of Agriculture and Food Systems, 489-503. https://doi.org/10.1016/B978-0-444-52512-3.00123-6

[3] Binswanger-Mkhize, H. and McCalla, A.F. (2010) The Changing Context and Prospects for Agricultural and Rural Development in Africa. Handbook of Agricultural Economics, 4, 3571-3712. https://doi.org/10.1016/S1574-0072(09)04070-5

[4] Diaz-Bonilla, E. and Sherman, R. (2010) Macroeconomics, Macrosectoral Policies, and Agriculture in Developing Countries. Handbook of Agricultural Economics, 4, 3035-3213. https://doi.org/10.1016/S1574-0072(09)04061-4

Submit or recommend next manuscript to SCIRP and we will provide best service for you:

Accepting pre-submission inquiries through Email, Facebook, LinkedIn, Twitter, etc. A wide selection of journals (inclusive of 9 subjects, more than 200 journals)

Providing 24-hour high-quality service

User-friendly online submission system

Fair and swift peer-review system

Efficient typesetting and proofreading procedure

Display of the result of downloads and visits, as well as the number of cited articles

Maximum dissemination of your research work

Submit your manuscript at: http://papersubmission.scirp.org/

Or contact wjet@scirp.org 